\title{
A case of aural myiasis caused by Wohlfahrtia magnifica in a child in Turkey
}

\section{Türkiye'de bir çocukta Wohlfahrtia magnifica'nın neden olduğu kulak miyazı vakası}

\author{
Yunus Emre BEYHAN1, Hasan YILMAZ1', Zeynep TAS-CENGiZ1', Abdurrahman AYRAL²
}

\begin{abstract}
Myiasis is the infestation of tissues and organs of vertebrate animals and humans by the larval stages of dipterous flies. In present case, a four year old child living in Silopi was applied to our clinic with complaints of otalgia, pruritus and otorrhea in the right ear. In the physical examination, aural fetor, secretion and several foreign bodies were observed. Twenty living maggots were removed from the external auditory canal (EAC) using surgical forceps. The maggots were identified as third phase larvae of Wohlfahrtia magnifica. In conclusion, patient should be examined for aural myiasis in case of otalgia, otorrhea, itching, and hearing impairments, especially in children.
\end{abstract}

Anahtar Kelimeler : Aural Myiasis, Wohlfahrtia magnifica, Diptera, Turkey

\section{ÖZET}

Miyaz, omurgalı hayvan ve insanların doku ve organlarının diptera dizisindeki sinek larvaları ile istilasıdır. Bu olguda, Silopi'de yașayan dört yașında bir çocuk hasta sağ kulağında ağrı, kașıntı ve akıntı şikayetleriyle polikliniğe bașvurmuștur. Fizik muayenesinde çok sayıda yabancı cisim, akıntı ve ișitme kaybının olduğu görülmüștür. Cerrahi pens yardımıyla 20 adet canlı larva orta kulak ve diș kulak yolundan çıkarılmıștır. Parazitoloji laboratuvarında yapılan incelemede kurtçukların 3. dönem Wohlfahrtia magnifica larvası olduğu tespit edilmiștir. Sonuç olarak, kulak ağrısı, kulak akıntısı, kaşıntısı ve ișitme kaybı yașayan özellikle çocuk hastalar kulak miyazı yönünden muayene edilmelidir.

Key Words: Kulak Miyazı, Wohlfahrtia magnifica, Diptera, Türkiye

'Department of Medical Parasitology, Yuzuncu Yil University Faculty of Medicine, Van

${ }^{2}$ Department of Otorhinolaryngology, Yuzuncu Yil University Faculty of Medicine, Van

İletişim/ Corresponding Author : Yunus Emre BEYHAN

Yüzüncü Yıl Üniversitesi Tıp Fakültesi Tıbbi Parazitoloji Anabilim Dalı 65080 Van - Türkiye

Tel : +90 5069952525 E-posta/E-mail : yebeyhan@gmail.com 


\section{INTRODUCTION}

Myiasis is the infestation of tissues and organs of vertebrate animals and humans by the larval stages of dipterous flies (1). The infestations can be caused by many fly species although the most common agents are members of the Calliphoridae, Sarcophagidae, Oestridae, and Muscidae families (2). The larvae of fly feed on the living and dead/necrotic tissues, ingest food or body fluids of the host for a certain period of time (3). The most commonly infested areas are subcutaneous tissue, mouth, intestines, urogenital system, nose and ears (4). Clinical symptoms and the damages vary based on the body site affected, agent species and number of maggots (5).

The infestation with fly larvae has a worldwide distribution, however since the flies prefer hot and humid environments, high prevalence rates occur in tropical and subtropical regions (1). Healthy people are less predisposed and low socioeconomic regions and poor hygiene are the main risk factors for occurrence of the myiasis (3).

Myiasis may be classified in two different ways. The first classification is based on etiologically: obligatory, facultative and accidental myiasis, while the second classification is clinical (based on the affected body part), e.g., cutaneous, aural, ocular, nasal, oral, vaginal, anal, intestinal and urinary myiasis (4-5). In humans, the most frequently observed form is cutaneous myiasis, and it is morphologically divided into three forms: wound (traumatic), furuncular and creeping (migratory) myiasis. Species of flies causing human myiasis are mostly from the Calliphoridae and Sarcophagidae families (6).

Wohlfahrtia magnifica belong to the family of Sacrophagidae and causes obligatory myiasis and prefers body orifices such as ears, eyes, and nose. The maggots infest healthy or damaged living tissues. It is also one of the flies responsible for traumatic myiasis. This fly is found in Mediterranean basin, southern Russia, Middle East, North Africa, Central Europe and Central Asia (7-8). Infestations generally occur during the summer, which is the adequate season for reproduction of the flies. The female Wohlfahrtia deposit their larvae directly on the host and after feeding for approximately one week the larvae cause serious clinical symptoms (3-8). In the present case we report an aural myiasis induced by $W$. magnifica larvae in a child patient in Van province of Turkey.

\section{CASE}

In June 2016, a 4 year old child living in a socioeconomically poor family from Silopi was referred to the Otorhinolaryngology Department of our hospital. He had complaints of otalgia, pruritus and otorrhea in the right ear for the last two days. In the physical examination, aural fetor, secretion and several foreign bodies were observed in the aural cavity (Figure 1).

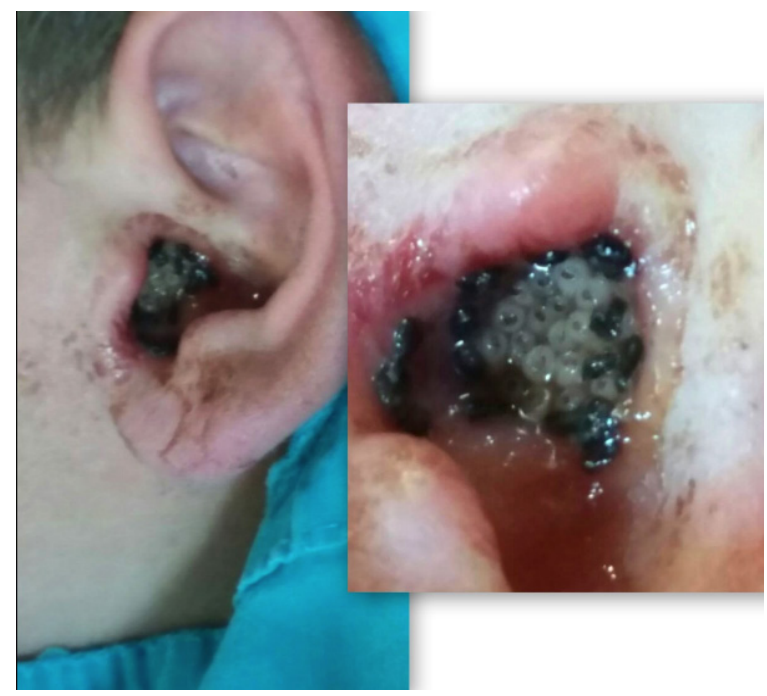

Figure 1. Maggots in the aural cavity

The patient was anesthetized for surgery and undergone an otoscopic examination, when 20 living maggots were removed from the external auditory canal (EAC) using surgical forceps. Examination of the patient's ear revealed that the tympanic membrane was perforated, while no other pathological changes were observed. After the removal of the larvae, antiseptic dressings were applied to the EAC. Collected larvae were sent to the Laboratory of Medical Parasitology for identification. They were fixed in $70 \%$ ethanol, 
and laved in a $10 \% \mathrm{KOH}$ solution. Maggots measured approximately $1.2-1.5 \mathrm{~cm}$ in length. For a detailed visual examination of the larvae, specimens were treated with lactophenol and examined on a glass slide under at light microscope. Morphological examination of the anterior spiracles, cephalopharyngeal skeleton, posterior peritreme and spines allowed the identification of the maggots as the third phase larvae of $W$. magnifica, the anterior spiracles having five branches and the peritremes three splits (Figure 2).

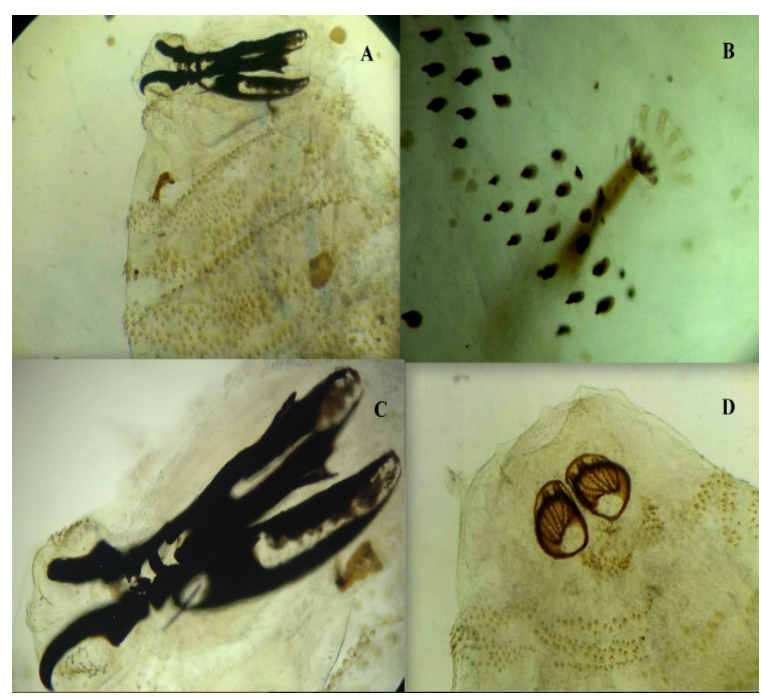

Figure 2. A) Front view B) anterior spiracles C) cephalopharyngeal skeleton D) posterior peritrem and spines of $W$. magnifica

Local antibiotic therapy was applied for prevention of secondary infections. The patient returned to the clinic for follow-up after one week of the therapy and neither larvae nor pathological findings were observed at the otoscopic examination. In addition, the patient stated that he had no more complaints in the ear.

\section{DISCUSSION}

Various fly species are able to cause myiasis in humans. Since body secretions are attractive for these flies, they are the main causes of the myiasis of wound and of external orifices. W. magnifica infests a great number of animals while humans are considered to be occasional hosts. The adult insect flies during the hot season and the warm hours of the day (9). It is mainly found in the Mediterranean basin, southern Russia, Middle East, North Africa and the southern Europe (78).

In humans, myiasis occurs predominantly in unhealthy individuals usually living in rural areas (3). Low socioeconomic status, low educational level, poor hygiene, advanced age, mental retardation, alcoholism and diabetes are the predisposing factors for the infestation (10). However, W. magnifica could also infest humans without any such predisposing factors (11).

W. magnifica has been reported as the causative agent of different types of myiasis including orotracheal (12), aural (13), furuncular (14), oral (15), mastoidectomy cavity (16), otomyiasis (17), and cutaneous myiasis (18) in Turkey, in addition to these orbital (19), gingival (20), and urogenital (21) myiasis reported in different countries. There are limited number of publications regarding human aural myiasis caused by W. magnifica (22), Lucilia sericata (23) and Chrysomya bezziana (24).

Generally, clinical course of myiasis is asymptomatic or may be accompanied by minor symptoms depending on the location of infestation, species and the number of maggots. W. magnifica larvae usually feed superficially on the epidermis. It could damage healthy tissues and after a while could cause pain (10). Aural infestations occur frequently in patients with poor personal hygiene, children and also adults with intellectual disabilities (22). In a study recently it was mentioned that aural myiasis is usually observed in children under 10 (3). This is in agreement with our case, in which the infested patient was a child with poor hygiene.

Aural myiasis can show a wide clinical spectrum of symptoms that includes otalgia, bleeding, otorrhea, itching, perforation of the tympanic membrane, malodor, tinnitus, itching, discomfort and hearing loss. Furthermore, some severe symptoms and complications such as deafness, penetration within the central nervous system, tissue destruction and 
extensive necrosis may also occur. Infestation of the ear could become dangerous due to penetration to brain and fatality rate may reach $8 \%(3,8)$. In our case, the symptoms were otorrhea, otalgia, aural itching and perforation of the tympanic membrane. The maggots were removed from EAC, where the maggots could easily pass into cranium.
Myiasis is not common in patients with complaints in the ear region, thus, the possibility is rarely considered. Even so, patient should also be examined for aural myiasis in case of otalgia, otorrhea, itching, and hearing impairments, especially in children. Antibiotics must be administered to prevent secondary bacterial infections.

\section{KAYNAKLAR}

1. Meinking TL, Burkhart CN, Burkhart CG. Changing paradigms in parasitic infections: common dermatological helminthic infections and cutaneous myiasis. Clin Dermatol, 2003; 21: 407-16.

2. Hall MJR, Farkas R. Traumatic myiasis of humans and animals. Papp L, Darvas B, editors. Contributions to a Manual of Palaearctic Diptera. Vol 1: General and Applied Dipterology. Budapest: Science Herald, 2000: 751-68.

3. Francesconi F, Lup O. Myiasis. Clin Microbiol Rev, 2012; 25: 79-105.

4. Markell EK, David TJ, Krotoski WA. Fly larvae that cause myiasis. 8th edition. Philadelphia: WB Saunders Company, 1999.

5. John DT, Petri WA. Markell and Voge's Medical Parasitology. 9th edition. USA: Saunders, Elsevier, 2006: 328-35.

6. Hall M, Wall R. Myiasis of humans and domestic animals. Adv Parasitol, 1995; 35: 257-334.

7. Goddard J. Flies whose maggots cause myiasis in humans. In: Physician's Guide to Arthropods of Medical Importance, 2nd edn. Florida: CRC Press, 1996: 169-87.

8. Noutsis C, Millikan LE. Myiasis. Dermatol Clin, 1994; 12: 729-36.

9. Ruiz Martinez I, Soler Cruz MD, Benitez Rodriguez R. Postembriyonic development of Wohlfahrtia magnifica (Schiner, 1862) (Diptera: Sarcophagidae). J Parasitol, 1989; 75: 531-9.

10. Colebrook E, Wall R. Ectoparasites of livestock in Europe and the Mediterranean region, Vet Parasitol, 2004; 120: 251-74.

11. Hall MJ. Trapping the flies that cause myiasis: Their responses to host-stimuli. Ann Trop Med Parasitol, 1995; 89: 333-57.

12. Çiftçioglu N, Altintas K, Haberal M. A case of human orotracheal myiasis caused by Wohlfahrtia magnifica. Parasitol Res, 1997; 83: 34-36.

13. Yuca K, Caksen H, Sakin FY, Yuca SA, Kırıș M, Yılmaz $\mathrm{H}$, Çankaya $\mathrm{H}$. Aural myiasis in a children and literature review. Tohoku J Exp Med, 2005; 206: 125-130.
14. Tuygun N, Özkan AT, Tanır G, Mumcuoğlu K. Furuncular myiasis in a child caused by Wohlfahrtia magnifica (Diptera: Sarcophagidae) associated with eosinophilia. Turkish J of Pediatr, 2009; 51: 279-81.

15. Yazar S, Dik B, Yalçın S, Demirtaș F, Yaman O, Öztürk $M$, Şahin I. Nosocomial Oral Myiasis by Sarcophaga sp. in Turkey Yonsei Med J, 2005; 46(3): 431-4.

16. Uzun L, Cinar F, Beder LB, Aslan T, Altintas K. Radical mastoidectomy cavity myiasis caused by Wohlfahrtia magnifica. J Laryngol Otol, 2004; 118: 54-6.

17. Karaman E, Samasti M, Saritzali G, Ozdemir S, Halil MC, Isildak H. Otomyiasis by Wohlfahrtia magnifica. J Craniofac Surg, 2009; 20 (6): 2123-34.

18. Kokcam I, Saki CE. A case of cutaneous myiasis caused by Wohlfahrtia magnifica. J Dermatol, 2005; 32: 459-63.

19. Maurya RP, Mishra D, Bhushan P, Singh VP, Singh MK. Orbital Myiasis: Due to Invasion of Larvae of Flesh Fly (Wohlfahrtia magnifica) in a Child; Rare Presentation. Ophthal Med, 2012; 371498: 1-2.

20. Tang $\mathrm{H}$, Wang XW, Tang GH. Two cases with gum myiasis caused by Wohlfahrtia magnifica. Zhongguo Ji Sheng Chong Xue Yu Ji Sheng Chong Bing Za Zhi, 2003; 21: 30.

21. Salimi M, Goodarzi D, Karimfar MH, Edalat $H$. Human Urogenital Myiasis Caused by Lucilia sericata (Diptera: Calliphoridae) and Wohlfahrtia magnifica (Diptera: Sarcophagidae) in Markazi Province of Iran. Iranian J Arthropod-Borne Dis, 2010; 4: 72-6.

22. Panu F, Cabras G, Contini C, Onnis D. Human auricolar myiasis caused by Wohlfartia magnifica (Schiner) (Diptera: Sarcophagidae): first case found in Sardinia. J Laryngol Otol, 2000; 114: 450-2.

23. Kaczmarczyk D., J. Kopczyński, J. Kwiecień, M. Michalski and P. Kurnatowski. The human aural myiasis caused by Lucilia sericata. Wiad Parazytol, 2011; 57: 27-30.

24. Rohela M, Jamaiah I, Amir L, Nissapatorn V. A case of auricular myiasis in Malaysia. Southeast Asian J Trop Med Public Health, 2006; 37: 91-4. 